\title{
攪乱された粘土凍土の力学的特性に関する実験的研究

\author{
AN EXPERIMENTAL STUDY ON MECHANICAL PROPERTIES \\ OF DISTURBED FROZEN CLAY
}

\author{
榎戸源則* ·龟田淳二** · 永瀬 英生 ${ }^{* * *}$-鵜 飼恵三**** \\ By Motonori ENOKIDO, Junji KAMETA, Hideo NAGASE and Keizo UGAI
}

\begin{abstract}
There have been nothing or few studies on the effect of disturbing frozen soils. An experimental study was carried out by using artificial undisturbed clay samples and was investigated by regression analysis. The obtained main conclusions are as follows. (1) The compressive strength and deformation modulus of frozen clay increased slightly by disturbing. (2) The reason why the strength and deformation modulus increase by disturbing seems to depend on decreasing of water content and increasing of dry specific gravity by disturbing. (3) If high sensitivity clay is frozen, its sensitivity ratio becomes nearly 1 and is not sensitive. (4) The more lime adds to clay, the less strength of unfrozen clay becomes, However, these effect almost disappear, if such a clay is frozen.

Keywords : frozen clay, compressive strength, modulus of deformation, disturbing, undisturbing
\end{abstract}

\section{1. まえがき}

凍土の工学的研究（低温土質工学）がまだ緒についた ばかりであることは，第一著者が繰り返して述べてきた とおりであり, 低温土質工学上, 残された未解明の問題 は多いように思われる. 本研究においては, 凍土試料の 筧乱・不摫乱の影響を取り上げることにする．この問題 も, 凍土の力学的特性に関する基礎研究課題としては残 された重要な研究課題の 1 つであると考えられる.

末凍土（常温の土）の場合, 試料が摜乱されているか 否かは, 重要な条件の 1 つとなるから, 凍土の場合も, 当然無視できないであろうことは, 容易に推測される. この問題に関する研究も, 不凍水の研究と同じようにき わめて少ない。これは，土質工学会の「凍土の力学特性 に関する研究委員会」が, 1984 年 1 月から 1985 年 4 月 までに行った文献調查の結果からも明らかである11.

本研究では, カオリン粘土を用いて, また石高を添加

* 正会員 工博 群馬大学教授 工学部建設工学科 ( ₹ 376 桐生市天神町 1-5-1)

** 学生会員 群馬大学大学院工学研究科建設工学専攻 (現・群馬県庁) (同上)

*** 正会員 工博 群馬大学助手 工学部建設工学科 (同上)

**** 正会員 工博 群馬大学助教授 工学部建設工学科 (同上)
したカオリンにより人工的に不摫乱試料を作製し，筧乱 した試料との力学的特性について, 一軸圧縮強度試験結 果により比較検討した. 力学的特性としては, 主として は, 圧縮強度亡変形係数を取り上げた。 また，未凍土に ついても実験を行い, 凍土の場合と比較検討を行った. その結果, 凍土の場合は未凍土と異なり，摫乱の影響は ほとんぎなく, 圧縮強度, 変形係数とも, 不摫乱試料よ り增加する傾向がみられた。

なお，現場から採取した自然状態の不摫乱試料につい ても, 現在実験を行っており, 人工不覞乱試料との比較 を含めて次の機会に報告する予定である. 凍土について のこのような実験は，おそらく初めて行われたものであ り, 著者らの知る限りにおいて既往の研究も, 非常に少 ない2).このような基礎研究の結果は, 凍結工法や低温 地下タンクなどの問題解決に役立ち得ると考えられる.

\section{2. 実 験 概 要}

\section{（1）実験装置}

圧縮強度は, 一軸圧縮強度試験により行われた。一軸 圧縮強度試験装置は, 既設のアムスラ一試験機を断熱材 で被覆された供試体収納器により，供試体試験部分の装 置を覆い，液体窒素を供給することにより，供試体を一 定温度状態で試験することを可能にする. その他, 温度 
制御装置，荷重・変位増幅および自動記録，液体窒素貯 蔵器からなる. $30 l$ 容量の液体窒素貯蔵器は, 液体窒素 くみ上げポンプにより，自動的に保冷配管を通して，供 試体内に液体窒素を供給し, 試験中一定温度となる役割 を果たす. 荷重は荷重増幅器に, 変位計は変位増幅器に 接続され，自動監視および記録計（ハイブリッドグラ ファー, Hybrid Grapher) により記録される.この装 置により，応力-ひずみ曲線のグラフが，それぞれの温 度に対して自動記録される。これが本実験装置の特徵の 1 つとなっている.

\section{（2）供試体の作製と実験方法}

摫乱・不摫乱の影響差異を調べるためには，不摫乱試 料として，自然地盤から不摫乱試料を採取する方法がと られなければならないが，同一条件での試験を何回も行 う関係上，費用等の問題もあり，本研究においては，三 笠らの模型実験の方法にならい石高を加えた人工不攪乱 試料が用いられだ)

粘性土としては，土粒子比重 2.69 のカオリンを使用 した。その粒度分布は，参考文献 4) に用いられたもの と同じである.

a) 未凍土供試体 粉末状のカオリンを蒸溜水と混 合し，ペースト状にした後，圧密槽で圧密作製される. カオリンのみでは鋭敏比が小さいので，石高 $2 \%$ と 5 \%を添加した試料も用いられた。このようにして作製 された試料を JISに準じて一軸圧縮試験を行った。

b）凍土試料 未凍土供試体の場合と同様にして作 製された供試体を鋼製のモールドに入れ，フリーザー内 で $-30^{\circ} \mathrm{C}$ に凍結させた後，上記のような試験装置によ り，一軸圧縮強度試験を実施した．荷重速度は応力制御 とし, $200 \sim 300 \mathrm{kPa} / \mathrm{s}$ とした。

これらの供試体を用いて, それぞれの配合, 条件につ いて，おのおの 6 個ずつの実験を行った。

\section{3. 実験結果}

\section{（1）末凍土供試体の圧縮強度}

末凍土供試体の圧縮強度を表一1 に示す，その応力ひずみ曲線は図一1のようになる，ここで，応力にピー クがない場合は，一軸圧縮強度としてひずみ $10 \%$ のと きの応力 $\sigma_{10}$ を採用している.これは, 未凍土の場合, ひずみが $15 \%$ のときの応力 $\sigma_{15}$ を用いるのが一般的で あるが，凍土の場合には， $\sigma_{10}$ を用いるのが一般的になっ ているので5)，凍土と比較する関係上，凍土に合わせた 方がよいと考えて， $\sigma_{10}$ を用いたのである。したがって 末凍土の場合表一1 と図一4の $\sigma$ は不覞乱の場合はピー ク值を，摫乱の場合は $\sigma_{10}$ を示す。

表一1 の最確値 $\sigma$ は, 6 回の実験值の平均値であり, その信頼区間は次式で算定される。

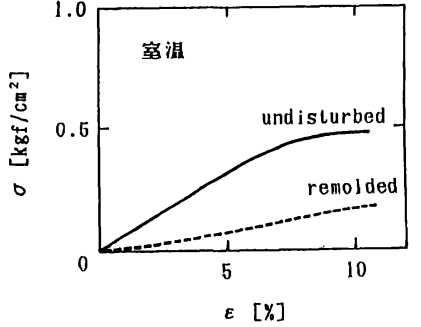

図一1 カオリンの人工地盤から作製した供試体の応カーひずみ 曲線

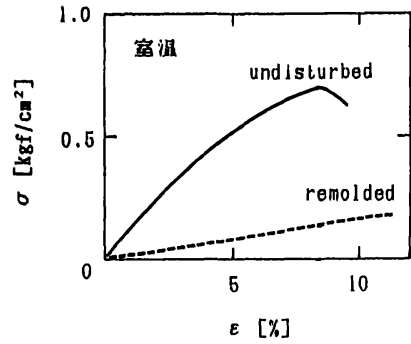

図一2 $2 \%$ の石高を添加した人工地盤から作製した供試体の応 カーひずみ曲線

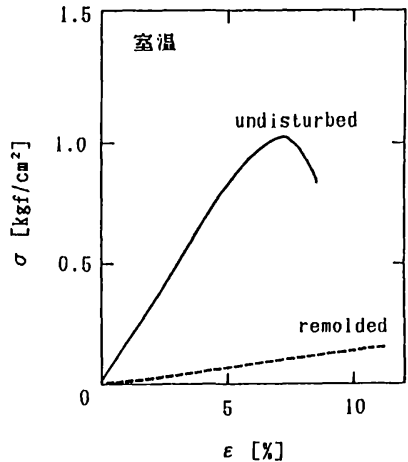

図一3 5\%の石衰を添加した人工地盤から作製した供試体の応 カーひずみ曲線

$$
\sigma=\bar{\sigma} \pm \sqrt{F_{1, n-1}\left(\frac{S^{2}}{n}\right)}
$$

ここに，

$$
\begin{aligned}
& S^{2}=\frac{\sum_{i}\left(\sigma_{i}-\bar{\sigma}\right)^{2}}{n-1} \\
& \quad n=6, \quad F_{1,5 ; 0.05}=6.61
\end{aligned}
$$

次に,カオリンのみでは, 鋭敏比が 2.9 と小さいので, 石高を $2 \%$ 添加した場合と $5 \%$ 添加した場合について 実験を行った．表一1 から明らかなように，石高を添加 すると, 鋭敏比はそれぞれ 4.3 および 7.4 へと大幅に増 加している．石高を添加した試料の応力ーひずみ曲線を 図一2, 図-3に示す. 図-1 3 から不覞乱の場合, 石 
表一1 未凍結供試体の強度

\begin{tabular}{|c|c|c|c|c|c|c|}
\hline 土 算 & 状㷛 & $\omega[\%]$ & $\mathrm{G}_{\mathrm{d}}$ & $\sigma[\mathrm{kPa}]$ & 95\%佰轵区蔺 & 额战比 \\
\hline カオリン & 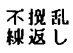 & $\begin{array}{l}36.68 \\
36.62\end{array}$ & $\begin{array}{l}1.300 \\
1.37\end{array}$ & $\begin{array}{l}46.8 \\
16.0\end{array}$ & $\begin{array}{r} \pm 3.8 \\
\pm 1.3\end{array}$ & 2.0 \\
\hline 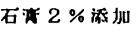 & $\begin{array}{l}\text { 不挜乱 } \\
\text { 粿返 }\end{array}$ & $\begin{array}{l}37.13 \\
36.34\end{array}$ & $\begin{array}{l}1.282 \\
1.35\end{array}$ & $\begin{array}{l}68.3 \\
15.8\end{array}$ & $\begin{array}{l} \pm 8.5 \\
\pm 0.8\end{array}$ & 4.3 \\
\hline 石青 $5 \%$ 添加 & $\begin{array}{l}\text { 不㨨乱 } \\
\text { 蚻返し }\end{array}$ & $\begin{array}{l}38.36 \\
37.68\end{array}$ & $\begin{array}{l}1.260 \\
1.32\end{array}$ & $\begin{array}{r}101.9 \\
13.8 \\
\end{array}$ & $\begin{array}{r} \pm 16.6 \\
\pm \quad 0.6\end{array}$ & 7.4 \\
\hline
\end{tabular}

表一2 凍土供試体の強度

\begin{tabular}{|c|c|c|c|c|c|}
\hline 土 & 状想 & $\omega[\%]$ & $G_{d}$ & $\sigma[\mathrm{MPa}]$ & 85\%佰䉼区用 \\
\hline カオリン & $\begin{array}{l}\text { 不摸乱 } \\
\text { 秤返 }\end{array}$ & $\begin{array}{l}36.75 \\
35.64\end{array}$ & $\begin{array}{l}1.269 \\
1.294\end{array}$ & $\begin{array}{l}11.4 \\
12.1\end{array}$ & $\begin{array}{l} \pm 0.2 \\
\pm 0.8\end{array}$ \\
\hline 石巷 $2 \%$ 添扗 & $\begin{array}{l}\text { 不括乱 } \\
\text { 株返し }\end{array}$ & $\begin{array}{l}37.48 \\
36.53\end{array}$ & $\begin{array}{l}1.268 \\
1.275\end{array}$ & $\begin{array}{l}12.0 \\
12.3\end{array}$ & $\begin{array}{l} \pm 0.1 \\
\pm 0.4\end{array}$ \\
\hline 石泀 $5 \%$ 添挑 & $\begin{array}{l}\text { 不抵乱 } \\
\text { 秤返 }\end{array}$ & $\begin{array}{l}38.65 \\
37.47\end{array}$ & $\begin{array}{l}1.251 \\
1.262\end{array}$ & $\begin{array}{l}12.7 \\
12.8\end{array}$ & $\begin{array}{l} \pm 0.1 \\
\pm 0.2 \\
\end{array}$ \\
\hline
\end{tabular}

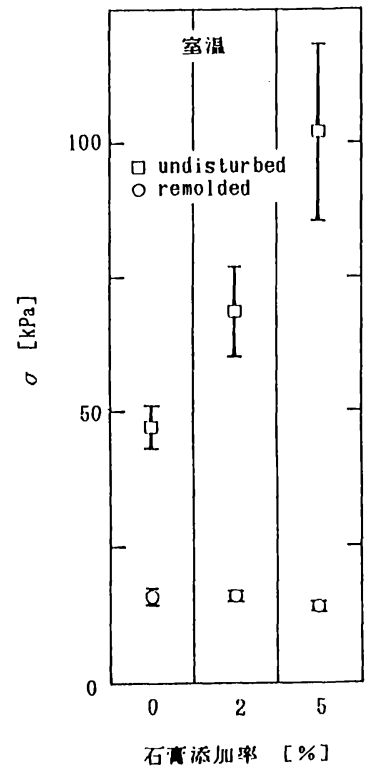

図一，末凍結供試体の強度

亨を添加した方が，また添加率が多くなるほど，応力一 ひずみ曲線のピークが明瞭になっていることがわかる. これら, 石高添加率の相違による未凍土の圧縮強度の差 異を示すと，図一4のようになる.

これらの結果から, 未凍土の場合は攪乱されると, 強 度は著しく低下することがわかる，その低下の度合は， 石高添加率が増加するほど著しい.

\section{（2）凍土供試体の圧縮強度}

凍土供試体の圧縮強度試験結果を表一2に示す．また， その応力ーひずみ曲線は，図一5，図一6 および図一7 の ようになる。これらの結果によると，凍土の場合は摜乱 の影響はほとんどみられず，むしろ攪乱試料の方が，不 摫乱試料より圧縮強度の值がやや大きめになっているこ とがわかる.

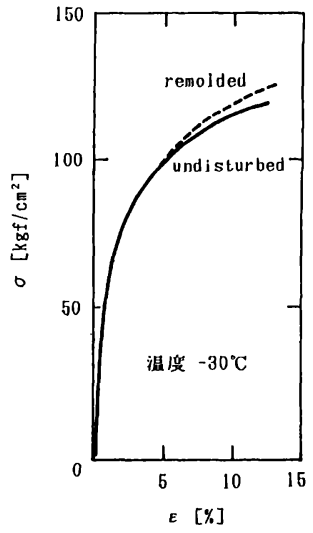

図一5 カオリンの人工地盤から作製した 凍土供試体の応力ーひずみ曲線

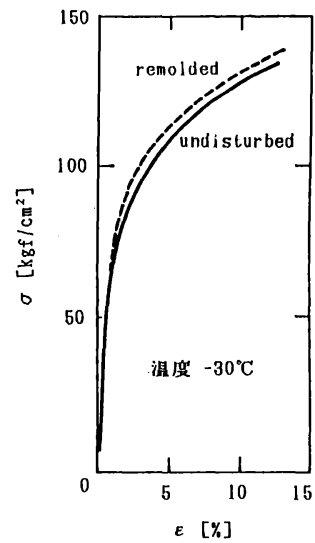

図一75\%の石專を添加した 人工地盤から作製した 凍土供試体の応カーひ ずみ曲線

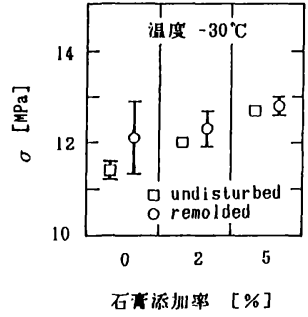

図一8 凍土供試体の強度

次に，石膏添加率亡圧縮強度との関係を示すと図一8 のようになる，各石高添加率の相違による強度の差異が ほとんどみられないこともわかる。

(3) 変形係数

凍土の変形係数之一軸圧縮強度との間には, 正比例的 な関係があるという実験結果が報告されている(6) 8). こ 


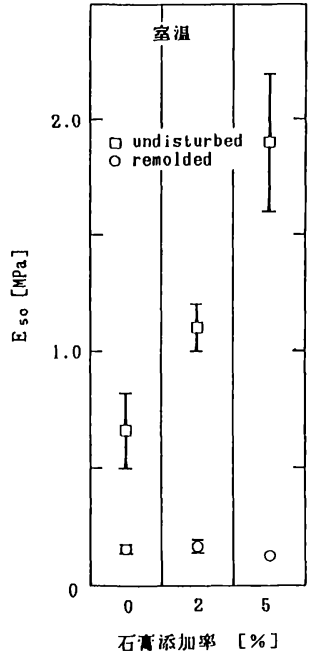

図一9 未凍結供試体の変形 係数

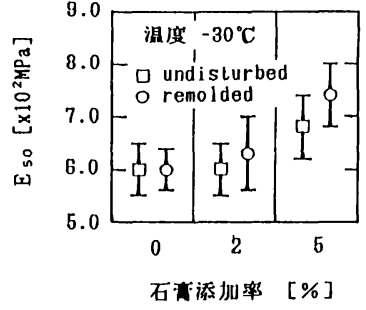

図一10 凍土供試体の変形 係数

こに変形係数としては, 粘性土に対する変形係数として 一般に用いられている $E_{50}$ を用いる。.ここに， $E_{50}$ とは 次式で定義される ${ }^{9)}$.

$$
E_{50}=\frac{\sigma_{10} / 2}{\text { (忍力が } \sigma_{10} / 2 \text { のときのひずみ) }}
$$

したがって, 変形係数に及ぼす影響については, 圧縮 強度と同じようなことがいえるのではないかと予测され る. 未凍土供試体の変形係数については, 表一6に示す ような值となる，擤乱すると，不覞乱の場合より著しく 減少することがわかる. 図一9は, 石高添加率と変形係 数との関係を示す. 図一-9によると，石高添加率が増加 すると, 不摫乱土の変形係数は, 著しく増加するが, 摫 乱土は, 石亭添加率に無関係にほぼ一定となり, むしろ やや低下する傾向を示している.

表一7は，凍土供試体の変形係数の值を示す．変形係 数の場合も，圧縮強度と同じように，摫乱の影響はほと んよ゙みられず，逆にやや増加する傾向を示す．この関係 を石膏添加率と変形係数との関係で図示すると, 図一10 のようになる，圧縮強度の場合と同じように，石高添加 率の相違による变形係数の増加はほとんよ゙みられず，添 加率 $5 \%$ においてやや増加しているに過ぎない.

\section{4. 分散分析による検討}

以上の実験結果について, 分散分析による検討を加え る. 分散分析の方法は, 参考文献 4）による方法と同様 の手法による(0),11).

前述の実験結果によって明らかなように, 凍土供試体 と末凍土供試体では摫乱の影響が全く異なる．未凍土の 状態のとき，擤乱の影響に鋭敏な地盤から作製された供

表一3 カオリンの人工地盤から作製した凍土供試体の強度の分 散分析表

\begin{tabular}{|c|c|c|c|c|}
\hline 要 因 & 自由度 & 2 乘和 & 䎲均 2 平 & F 枳定 \\
\hline $\begin{array}{l}\text { 永均 } \\
\text { 練返 美 }\end{array}$ & $\begin{array}{r}1 \\
1 \\
10\end{array}$ & $\begin{array}{r}1652.05 \\
1.33 \\
2.85\end{array}$ & $\begin{array}{c}1652.05 \\
1.33 \\
\\
\\
0.285\end{array}$ & $\begin{array}{l}5.8\left(10^{3}\right) \\
4.67\end{array}$ \\
\hline 合 & 12 & 1656.23 & & \\
\hline
\end{tabular}

表一4 $2 \%$ の石亩を添加した人工地盤から作製した凍土供試体 の強度の分散分析表

\begin{tabular}{|c|c|c|c|c|}
\hline 袈 因 & 自的度 & 2 乘和 & 行均 2 果 & F梌定 \\
\hline 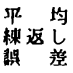 & $\begin{array}{r}1 \\
1 \\
10\end{array}$ & $\begin{array}{r}1771.47 \\
0.40 \\
0.83\end{array}$ & $\begin{array}{r}1771.47 \\
0.40 \\
\\
0.083\end{array}$ & $\begin{array}{l}2.1\left(10^{4}\right) \\
4.82\end{array}$ \\
\hline 合 計 & 12 & 1772.70 & & \\
\hline
\end{tabular}

表一5 $5 \%$ の石桼を添加した人工地盤から作製した凍土供試体 の強度の分散分析表

\begin{tabular}{|c|c|c|c|c|}
\hline 要 因 & 自由度 & 2 乘和 & 双均 2 霜 & F模定 \\
\hline 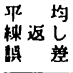 & $\begin{array}{r}1 \\
1 \\
10\end{array}$ & $\begin{array}{c}1945.65 \\
0.003 \\
0.26\end{array}$ & $\begin{array}{rr}1845.65 \\
\quad 0.003 \\
& 0.026\end{array}$ & $\begin{array}{l}7.5\left(10^{4}\right) \\
0.1\end{array}$ \\
\hline 合 & 12 & 1945.81 & & \\
\hline
\end{tabular}

$F_{1,10: 0.01}=10.04 \quad F_{1}, 10: 0.05=4.96$

表一 6 末凍結供試体の変形係数

\begin{tabular}{|c|c|c|c|}
\hline$\pm \quad r$ & 状想 & $\mathrm{E}_{50}[\mathrm{kPa}]$ & 85\%佰赖区间 \\
\hline カオ্ンリ & $\begin{array}{l}\text { 不规乱 } \\
\text { 稆返 }\end{array}$ & $\begin{array}{l}6.6\left(10^{2}\right) \\
1.6\left(10^{2}\right)\end{array}$ & $\begin{array}{l} \pm 1.6\left(10^{2}\right) \\
\pm 0.2\left(10^{2}\right)\end{array}$ \\
\hline 石青 $2 \%$ 添扣 & 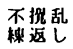 & $\begin{array}{l}1.1\left(10^{3}\right) \\
1.7\left(10^{2}\right)\end{array}$ & $\begin{array}{l} \pm 0.1\left(10^{3}\right) \\
\pm 0.3\left(10^{2}\right)\end{array}$ \\
\hline 石青 $5 \%$ 添 & 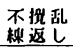 & $\begin{array}{l}1.9\left(10^{3}\right) \\
1.3\left(10^{2}\right)\end{array}$ & $\begin{array}{l} \pm 0.3\left(10^{3}\right) \\
\pm 0.1\left(10^{2}\right)\end{array}$ \\
\hline
\end{tabular}

\section{表一7 凍土供試体の変形係数}

\begin{tabular}{|c|c|c|c|}
\hline$\pm \quad$ K & 状倪 & $E_{50}\left[\times 10^{2} \mathrm{MPa}\right]$ & $95 \%$ 俉赖区州] \\
\hline カオリン & $\begin{array}{l}\text { 不掀乱 } \\
\text { 秤返し }\end{array}$ & $\begin{array}{l}6.0 \\
6.0\end{array}$ & $\begin{array}{l} \pm 0.5 \\
\pm 0.4\end{array}$ \\
\hline 石㳻 $2 \%$ 添打 & $\begin{array}{l}\text { 不溌乱 } \\
\text { 練返 }\end{array}$ & $\begin{array}{l}6.0 \\
6.3\end{array}$ & $\begin{array}{l} \pm 0.5 \\
\pm 0.7\end{array}$ \\
\hline 石苚 $5 \%$ 添扎 & $\begin{array}{l}\text { 不㧥乱 } \\
\text { 級返 }\end{array}$ & $\begin{array}{l}6.8 \\
7.4 \\
\end{array}$ & $\begin{array}{l} \pm 0.6 \\
\pm 0.6 \\
\end{array}$ \\
\hline
\end{tabular}

試体であっても，凍結させてしまうと，鋭敏でなくなっ てしまう. 石高 $5 \%$ 添加の鋭敏比 7.4 の未凍土が，一 $30^{\circ} \mathrm{C}$ の凍土になると, 不摫乱土, 摫乱土ともほとんど 変わらぬ圧縮強度を示している. 凍土においても鋭敏比 という概念が，末凍土と同じように用いられるとするな らば，この場合，鋭敏比が 1 であるといえよう.

そこで，いま「凍土供試体については，不摫乱の影響 はない」という帰無仮説をたて, 一元配置法による分散 分析によって検証してみる4). その結果は，表一3，表 -4 および表一 5 のようになる．表一3 がカオリン 100 \% の場合, 表一4および表一5 は, 石高添加率がそれぞ れ $2 \%$ および $5 \%$ の場合を示している.いずれの場合 も, 有意水準 (危険率) $5 \%$ で, 上記の仮説は正しいこ 
とが検証される．すなわち，カオリン粘土が凍結される と, 不覧乱の影響は, 実験誤差範囲に含まれる程度になっ てしまうといえることになる.

\section{5. 考察}

このような実験結果と分散分析の結果をふまえて，考 察を試みる。

分散分析の結果によると,カオリン粘土は凍結すると, 攪乱の影響はなく，その影響は実験誤差範囲内に入って しまうことになる。しかし，表一2 および図一 $-5 ， 6 ， 7$ ， 8 をみると, 攪乱されたカオリン凍土は，不攪乱試料よ り圧縮強度がやや大きくなっている傾向がみられる.こ れは，どのように説明したらよいであろうか．この原因

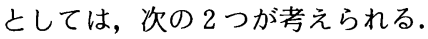

(1) 䚋乱, 練返しにより土粒子の配列が変化し, 凍結 によりさらに土粒子間の緊結, 付着効果のごときプ ラスの要因が作用する.

(2) 擤乱, 練返しにより, 含水比 $w$ が減少し, 締固 め効果により, 乾燥比重 $G_{d}$ が増加し, これが強度 に直接影響を与える.

これ以外にも種々の要因が考えられるが，まず上記の 理由について議論を進める.

(1)の要因については，まさしく粘性土の物理化学的 考察が必要とされる. 未凍土の場合も，一度摜乱された 粘性土が，時間の経過とともに，覞乱による強度低下を 回復することは，一般に認められている．いわゆるシキ ソトロピーといわれている現象である ${ }^{12}$. 本研究の場合, 時間による強度回復は無視できる程度の短時間で実験が 行われており, また, 各供試体とも同じような試験条件
である.したがって，たとえ若干のシキソトロピー効果 による強度増加の影響があったとしても，ほとんど問題 はないものとみられる，ただ，凍土供試体の方が，再凍 結等により時間効果が長くなるので，時間による強度回 復も，末凍土よりも大きくなると考えられる．いずれに せよ, このような物理化学的要因は, 定量的評価が困難 である.

これに反し，(2)の要因の方は，(1)に比べると，若干 定量的評価が可能となる. まず表一2 を再び吟味してみ ると, 摫乱により含水比 $w$ は, いずれの配合の場合も 減少しており, 反対に, 乾燥比重 $G_{d}$ は増加している. この結果が強度增加に関係があるとすれば，説明がつき そうである，この現象は，摫乱，練返しにより，摫乱供 試体が作製されるとき，試料がモールドに充填される際 に生ずる物理的な変化により発生するとみてよい.

この現象は, 実験により直接確認できるが(13),14), 豊浦 砂について著者らが得た強度-含水比の関係図（図一11） を吟味してみる ${ }^{15)}$. 土質が砂と粘土の相違はあるが，こ の図から粘性土の場合を類推してみる.いま,試料をモ一 ルドに充填する際, 含水比は減少し, 乾燥比重が増加す るという変化について考えてみる.この際, 粘土の供試 体はほとんど飽和しているとみなせるので, 含水比 $w$ の減少, 乾燥比重 $G_{s}$ の増加という現象は, 図一11の $S_{r}=100 \%$ 線上を左上に進むとみてよいであろう. と すると, $G_{s}$ の増大に伴い圧縮強度 $q_{u}$ も増加する. この ように推論していくと，(2)の原因は，かなり明確に説 明可能なように考えられる. 著者は, 現在砂質土に続き, 粘性土 (関東口ーム) について, 含水比, 乾燥密度およ び飽和度が凍土の圧縮強度に及ぼす影響について, 引続

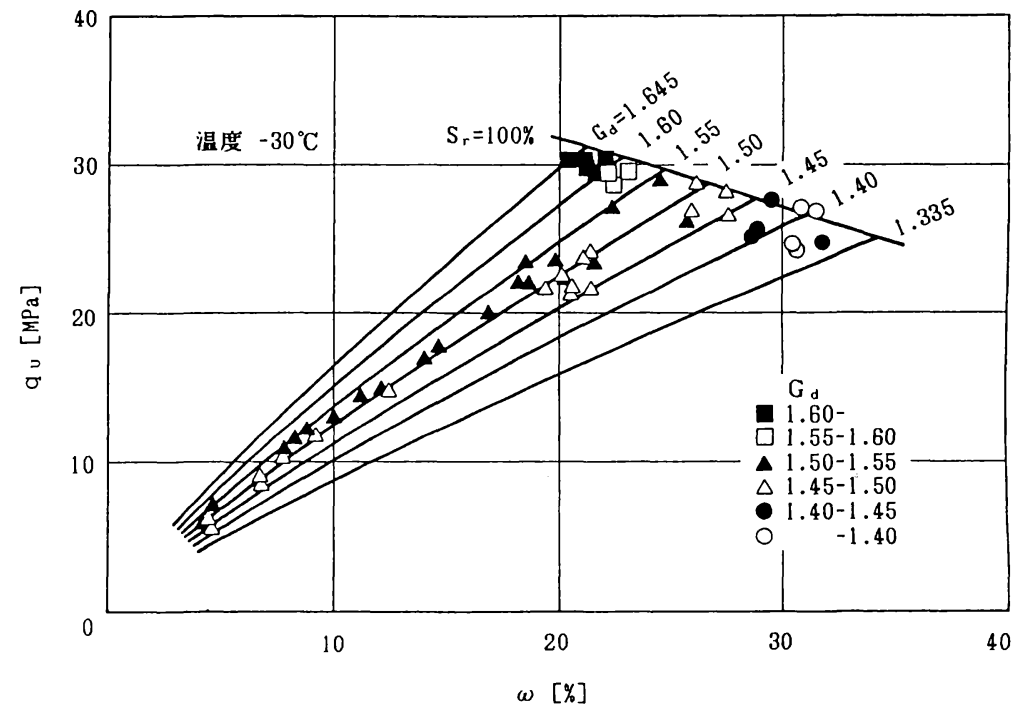

図一11 豊浦砂の強度-含水比図における等乾燥比重線 
き研究を行っており，近く報告する予定である．その結 果では, 粘性土についても, 同じような傾向がみられる ことが明らかにされた．すなわち， $S_{r}=100 \%$ の線は， 砂質土と同じく左上り（すなわち右下り）になっており， その勾配が粘性土になるほど，一層ゆるやかになる点が 異なるのみである.

以上の考察によると，(1)の要因の影響があるにせよ， (2)の要因が支配的であると推定してよさそうである.

次に, 変形係数について, 㹂乱の影響を考察してみる. 変形係数と強度とは，前述のように，正比例的関係にあ ることが一般に認められている。したがって，摫乱の影 響も圧縮強度と同様になることが，容易に推測される.

しかしながら，表一2 と表一7および図-8 と図-10 を比較すると, 石高を添加しない場合, 変形係数の值は 挸乱，不攂乱とも全く同じ值 $\left(6.0 \times 10^{2} \mathrm{MPa}\right)$ を示し， 摫乱の影響が全くないようにみえるが，圧縮強度は摫乱 により若干増加している，逆に，石高を添加しても，強 度はほとんど増加しないが, 変形係数の方は, 石高の添 加率が増えるほど,增加することが明らかに読み取れる. このような石高添加率の影響が, 圧縮強度と変形係数に 与える影響の相違については, 変形係数と圧縮強度が正 比例的関係にあるという通説と異なるのか否か,さらに， 実験を積み重ねる必要があると考えられる。

\section{6. 結 論}

凍土を覧乱した場合，その圧縮強度と変形係数にどの ような影響を与えるか，人工不筧乱試料を用いて実験を 行った. 既往の研究がほとんどない初めての実験研究で あるので，軽々に結論しかねる点もあるが，本研究の範 囲内では，次のようなことがいえると思われる.

（1）粘土凍土の圧縮強度と変形係数は，試料を翼乱 することにより，やや増加する傾向を示す．

（2）この主たる原因は，試料の筧乱，練返しによる 含水比の減少, 乾燥比重の増加による.

（3）凍結しない状態で鋭敏比の高い粘土を凍結させ ると，鋭敏でなくなってしまう．凍土の場合も未凍土と 同じような鋭敏比という定義が用いられるとするなら ば，粘土凍土の鋭敏比は 1 となる.

（4）粘土は，末凍結の場合，䚋乱により著しく強度 が低下する，その低下の割合は，石高添加率が増加する
ほよ゙著しくなる．しかし，凍結するとこのような影響は ほとんどみられない。

（5）粘土凍土の変形係数も，摫乱により圧縮強度と 同じような影響を受けるが，やや異なった傾向もみられ る.

\section{参 考 文 献}

1）土質工学会：凍土の力学特性に関する委員会, 土の凍結 に関するシンポジウム論文集, 凍土の一軸圧縮強度に係 わる供試体作製の現状と問題点, pp. 9 18，1986.

2）山本英夫 - 生頼孝博 - 岡本 純：挸乱 - 不摫乱凍土の一 軸圧縮特性に関する比較実験, 土木学会第 39 回年次学術 講演会 III, pp. 691 692, 1984.

3）三笠正人・高田直俊・望月秋利：遠心力を利用した士構 造物の模型実験, 土と基礎, Vol. 28, No. 5, pp. 15 23, 1980.

4）榎戸源則・亀田淳二：混合法による不凍水量測定法の評 価, 土木学会論文集 (投稿中)

5）高志 勤・生頼孝博・山本英夫・岡本 純：均質な粘土 凍土の一軸圧縮強度に関する実験的研究, 土木学会論文 報告集，第 315 号，pp. 83 93，1981 年 11 月.

6）片岡哲之・緒方信英・安田正幸 : LNG 地下タンク周辺地 盤の温度低下における強度変形特性, 電力中央研究所報 告, No. 378011, 1978.

7) 昭和 51 年度 LNG 地下式貯槽に関する保安調査報告書, （社）日本瓦斯協会，pp. 9 32, 1977.

8）後藤 茂·了戒公利・中沢 亨: 室内凍結砂の力学特性, 第 14 回土質工学研究発表会, pp. 497 500， 1979.

9）高志 勤・生頼孝博 - 山本英夫 - 岡本 純：砂凍土の一 軸圧縮強さに関する実験的研究, 土木学会論文報告集, 第 302 号, pp. 79 88, 1980 年 10 月.

10）石井恵一・堀 素夫 (共訳)：工科系のための統計概論, I. ガットマン/S.S. ウイルクス, 培風館, 1987.

11）田口玄一・横山巽子：実験計画法, 日本規格協会, 1987.

12) Yong, R. N. and Warkentin, B. P. (山内豊聡 - 竹中 肇・東山 勇・前田 隆共訳) : 新編土質工学の基礎, 鹿 島出版会, pp. 45〜 46, 1978.

13）高志 勤・生頼孝博 - 山本英夫：砂凍土の一軸圧縮強度 に及ぼす締固めの影響, 土木学会第 34 回年次学術講演会, pp. $235 \sim 236,1979$.

14）土質工学会：土の凍結一その制御と応用一, pp. $65 \sim 66$, 1982.

15) Enokido, M. and Kameta, J. : Influence of water content on compressive strength of frozen sands, Soils and Foundations, Vol.27, No.4, pp.148 152, 1987.

(1988.3.8 - 受付) 